\title{
Evaluation of Solid Minerals Inhibitory Potentials on Mildsteel Corrosion
}

\author{
Sodiya Ezekiel Folorunso ${ }^{1,}$ *, Aladesuyi Olanrewaju ${ }^{2}$, Egbure Florence Ebudola ${ }^{1}$, \\ Olagbende Odundayo Sunday ${ }^{3}$
}

${ }^{1}$ Chemistry Department (Industrial), Faculty of Science, University of Ibadan, Ibadan, Nigeria

${ }^{2}$ Chemistry Department, School of Science and Technology, Covenant University, Ota, Nigeria

${ }^{3}$ Beta Glass Plc, Guinea Plant, Agbara, Nigeria

\section{Email address:}

sodiyaezekiel@gmail.com (F. E. Sodiya), olanrewaju.aladesuyi@covenantuniversity.edu.ng (O. Aladesuyi), degbure@yahoo.com (E. F. Egbure), solagbende@frigoglass.com (O. S. Olagbende)

${ }^{*}$ Corresponding author

\section{To cite this article:}

Sodiya Ezekiel Folorunso, Aladesuyi Olarenwaju, Egbure Florence Ebudola, Olagbende Odundayo Sunday. Evaluation of Solid Minerals Inhibitory Potentials on Mildsteel Corrosion. International Journal of Materials Science and Applications. Vol. 6, No. 3, 2017 , pp. 112-118. doi: 10.11648/j.ijmsa.20170603.11

Received: November 3, 2016; Accepted: December 2, 2016; Published: March 14, 2017

\begin{abstract}
The use of some solid minerals in the inhibition of mild steel corrosion in acidic media was investigated using the conventional weight loss and hydrogen gas evolution method. Those considered are Talc, Gypsum, Alumina, Iron chromite and Haematite. Scanning electron microscope (SEM) and Electron Dispersive X-ray spectroscopy (EDX) studies revealed the protective effectiveness of the adsorbed film of the mineral extracts on the steel surface. Results obtained indicated the minerals inhibited corrosion of the steel in the order Talc $>$ Gypsum $>$ Haematite $>$ Alumina $>$ Chromite $>$ feldspar as the order of Inhibition efficiency. The resultant effect of solid minerals with Sida acuta plant extract is inhibitorily antagonistic due to induced corrosion rather than improve on the inhibition efficiency. Elements in the minerals got adsorped and reacted with the iron in steel to form a compound of effective protection of the metal against corrosion in its environment.
\end{abstract}

Keywords: Solid Minerals, Adsorption, Sida acuta, Metal Ore, Alumina, Gypsum, Haematite, Ironchromite and Talc

\section{Introduction}

Solid minerals are naturally occurring substances in the form of complexes and mixtures deposited in the ground with occasional outcrops. They are known to be abundant in nature, less expensive than their synthetic alternatives and most are non-toxic except few ones such as lead and chromates. They are categorized into metallic, non-metallic or carbonaceous. They are sources of raw materials for manufacturing industries and monumental [1].

Much energy is being expended in the extraction of metals from their ore especially the most electropositive ones due to strong bonds of elements involved in ore formation. In view of this, the pure form of the metals should have strong affinity to bond with highly electronegative elements that form ore constituents of a particular metal. The use of compound or ions of the elements contained in an ore as inhibitor for the pure form or already extracted metal is reactively expected to form a coat or complex by adsorption to the surface of the metal due to affinity specificity in reaction. Extracted metals are unstable in their pure state they tend to return to their ore form on exposure to the environment through oxidation reactions. This tendency of reversing the extraction process is corrosion. Metallic iron is extracted from ore of Magnetite $\mathrm{Fe}_{2} \mathrm{CO}_{3}$, Hematite $\mathrm{Fe}_{3} \mathrm{O}_{4}$ This pure iron have affinity for oxygen and moisture, it therefore corrodes. The oxide film of the reacting species formed on the metal surface act as a barrier for further redox reactions (adhesion). Some of them do contain inhibitive compounds or ions that may be synergized with plant extract to function as green inhibitor. On the other hand they may induce rather than inhibit corrosion in some medium. Some inhibitors retard corrosion by adsorption to form a thin, invisible film only a few molecules thick. Others form bulky 
precipitates that coat the metal and protect it from attack [2]. A lot of methods have been employed in preventing the corrosion of metals but the use of inhibitor is the most efficient method in most chemical processing industries. [3, 4]. As an environmentally required condition to have inhibitors that are safe, non-toxic and cheap, attention is now been focused on alternatives to the known form of inhibitors such as chromates and dichromate which are adjudged to be toxic and not environmentally friendly.

Gypsum $\mathrm{CaSO}_{4} \cdot 2 \mathrm{H}_{2} \mathrm{O}$ is a whitish chemical precipitate that occurred as thick stratified sediments associated as a deposit may occasionally be tinted with either of grey, yellow pink or buff colour depending on the nature of attached minerals. It is an intermediate material used in the manufacture of plasterboard and related products for building industries [5]. It can also be used in glass batch to produce $\mathrm{SO}_{2}$ gas an essential fining agent. Oxygen gas also produced along for effective oxidation and subsequent reaction path way for sodium sulphate formation, which is an intermediary compound for further oxidation reactions and also acts as anti-scumming agent in glass melt. Certain metals are largely resistant to gypsum, too, because the surfaces are coated with an oxide film that is stable to sulphate [6].

Haematite $\mathrm{Fe}_{2} \mathrm{O}_{3}$ which contains about $70 \%$ of $\mathrm{Fe}$ is produced from Pig Iron through blast furnace by the reduction of iron ore by coke. They are used in mixture with silicate for the manufacture of various forms of pigments for paints and linoleum fillers.

Feldspar could be potash microcline $\mathrm{K}_{2} \mathrm{O} \cdot \mathrm{Al}_{2} \mathrm{O}_{3} \cdot 6 \mathrm{SiO}_{2}$; soda albite $\mathrm{Na}_{2} \mathrm{O} \cdot \mathrm{Al}_{2} \mathrm{O}_{3} \cdot 6 \mathrm{SiO}_{2}$; lime anorhite $\mathrm{CaO} \cdot \mathrm{Al}_{2} \mathrm{O}_{3} \cdot 2 \mathrm{SiO}_{2}$ or mixture of these three in various proportions. It is a general fluxing compound used in whiteware industry for the manufacture of ceramics and related products such as pottery. It improves scratch, thermal and breaking resistance of glass when included in the glass batch [7]. It increases the chemical durability and decrease the tendency of devtrification in glass products. It also increases an enamel's viscosity at any given temperature.

Ironchromite $(\mathrm{MgFe}) \mathrm{O}(\mathrm{CrAlFe})_{2} \mathrm{O}_{3}$ is used for ferroalloy and chromium electroplating, chromium chemical productions, chromite bearing refractories, colourant in production of bottles, pigment in manufacture of gray face brick, ingredient for foundry washes and major constituent of some refractory mortars.
Talc $3 \mathrm{MgO} .4 \mathrm{SiO}_{2} \cdot \mathrm{H}_{2} \mathrm{O}$ soft white or light greenish white material is a cheap source of $\mathrm{MgO}$ which act as flux and provides the required strength in ceramics and tiles. It imparts high thermal and electrical resistance when used as insulators and in refractories that requires low thermal expansion [8[. Its resistance to acid attacks made it a material suitable for casing of appliances and equipment that needs to be structured through acute environments.

Alumina $\mathrm{Al}_{2} \mathrm{O}_{3}$, a material of several crystalline forms can be produced and also found as mineral corundum. It occurs in combined state as silicates in clay, kyanite, bauxites and laterites. It is used as abrasive for jewels of rugby and sapphire. Also used in ceramic products and applied into glass batch through feldspar [9].

Sida acuta plant is from the family Malvaceae. This is a dicot genus of about 200 species originated from Central America and occurring all over the warm tropics. A Pan tropical plant distributed and considered a common weed in most regions of the world. Shrubby perennial semi woody herbs, commonly found along road sides, waste places and rough grazing land [10]. Alkaloids such as Crytolepine5methylindolo (2-3b)-quinolic and Quidoline from Sida acuta isolated, characterized and investigated have been reported to be posses antibacterial activities that will inhibit microbiologically induced corrosion [11] Apart from phytoconstituents present in Sida acuta which made it a potential green inhibitor, it also contain the following minerals in mg/100mg: sodium 110; Calcium 85; phosphorus 65; Iron 4.87 and magnesium 24.5 [12].

This work aimed to study iron in their combined state with other elements to form an ore. The effect of some of the elements that freely reacted with iron to form an ore was been studied to confirm their corrosive or inhibitive role at ore formation and after.

\section{Materials and Method}

A steel pipe of $3.0 \mathrm{~mm}$ thickness was sliced into $18 \mathrm{~mm} \mathrm{x}$ $9 \mathrm{~mm}$, using saw on lathe machine. The coupons were degreased in absolute ethanol and washed in acetone and then dried in a desiccator. [13] Elemental composition of the steel was analysed using Metal Spectrometer Analyser of Model ARL Quanbo Desk OTD 226 (Optical emission) as shown in Table 1.

Table 1. Results of Percentage Elemental Composition of Mildststeel.

\begin{tabular}{|c|c|c|c|c|c|c|c|c|c|c|c|c|c|}
\hline Elements & C & Co & Mo & V & $\mathrm{Fe}$ & $\mathrm{Si}$ & Mn & $\mathrm{Nb}$ & $\mathrm{Cr}$ & $\mathbf{N i}$ & $\mathrm{Cu}$ & $\mathbf{S}$ & $\mathbf{P}$ \\
\hline$\%$ & 0.1551 & 0.0463 & 0.0106 & 0.0169 & 98.42 & 0.2378 & 0.5571 & 0.0823 & 0.0626 & 0.1499 & 0.0792 & 0.0445 & 0.0280 \\
\hline
\end{tabular}

\subsection{Digestion of Solid Minerals}

Small quantity of about $5 \mathrm{~g}$ of Gypsum, Hematite, Feldspar, Ironchromite and Alumina samples are finely ground separately from the representative sample. $1 \mathrm{~g}$ was taken out of this sample and weighed into a Platinum Dish moistened with distilled water. $4 \mathrm{~mL}$ of ratio [1:1] distilled water with concentrated $\mathrm{H}_{2} \mathrm{SO}_{4}$ and $14 \mathrm{~mL}$ of $40 \% \mathrm{HF}$ were added. The solution was heated on sand bath for $3 \mathrm{~h}$. The sample was cooled in water, open the lid and rinse into the dish with the sides of the dish rinsed with water, then $7 \mathrm{~mL}$ of $40 \% \mathrm{HF}$ is added. It was heated on a sand bath again for about $2 \mathrm{~h}$ until white fumes persist for 5-10 minutes. The lid was opened to allow cool. The content was transferred into a $250 \mathrm{~mL}$ Conical Flask, $20 \mathrm{~mL}$ of ratio [1:1] Distilled water with concentrated $\mathrm{HCl}$ and $30 \mathrm{~mL}$ of water was added (the water 
added was used to wash the sides of the flask). The solution was heated on the water bath without covering it for 20 minutes. $[14,15,16]$

\subsection{Extraction from Plant Leaves}

Fresh leaves of Sida acuta were dried and ground into powder. $10 \mathrm{~g}$ was weighed into $250 \mathrm{~mL}$ conical flask containing $100 \mathrm{~mL}$ ethanol using analytical balance Ohaus PA4102. The flask was properly corked and left to stand for $48 \mathrm{~h}$ with occasional shakings. The resultant mixture was filtered and residue thoroughly washed with ethanol. It was filtered and both filtrates added together. The extract was concentrated by use of rotary evaporator and the ethanol recovered. The concentrated extract was evaporated to oily solid on water by gently heating at $75^{\circ} \mathrm{C}$ to finally expel the leftover ethanol.

$1 \mathrm{~g}$ of the extract was dissolved in $1 \mathrm{~L}$ of $1.0 \mathrm{M} \mathrm{HCl}$ to make $1 \mathrm{gdm}^{-3}$ of the extract solution. All reagents were of Analar grade from (BDH Chemicals, England) and distilled water was used.

\subsection{Determination of Inhibition Rate of the Minerals by Weight Loss Method}

Weighed steel coupons of $18 \mathrm{~mm}$ by $8.5 \mathrm{~mm}$ by $3 \mathrm{~mm}$ thickness were immersed separately in $50 \mathrm{~mL}$ beaker containing $40 \mathrm{~mL}$ of digested solutions of $3 \mathrm{~g} / 100 \mathrm{~mL}$ of Gypsum, Hematite, Feldspar, Ironchromite, Alumina and a control of $1.0 \mathrm{M} \mathrm{HCl}$ at $30^{\circ} \mathrm{C}$. They were removed at $2 \mathrm{~h}$ and dropped in water to discontinue corrosion reaction. It was scrubbed with brittle brush under running water to remove the corrosion products. They were rinsed in ethanol and in acetone before final air drying and weighed. Each reading was recorded up to fourth decimal place using Ohaus PA4102 electronic analytical balance. The differences in weight of the coupons were taken as the weight loss.

\subsection{Determination of Inhibition Rate of the Minerals by Gasometric Method}

$50 \mathrm{~mL}$ of $1.0 \mathrm{M} \mathrm{HCl}$ solution (control) was introduced into Mylius Cell as shown in Figure 1. The coupon was dropped into the corrodent and corked airtight with vaseline. The hydrogen gas evolved by download displacement of water was recorded on the calibrated tube (inverted burrette). Readings were taken at every hour for $8 \mathrm{~h}$ at $30^{\circ} \mathrm{C}$. The experiment was repeated for digestion solutions containing $1.0 \mathrm{gdm}^{-3}$ of Talc and Gypsum. At the end of each experiment of Hydrogen gas Evolution (HE), the coupon was withdrawn from the tested solution, washed thoroughly with water followed by acetone and dried with air. [17] Both talc and gypsum were further synergized with plant Sida acuta plant extract at ratio 1:4 (extract: mineral).

Readings were taken in duplicates and recorded to $0.1 \mathrm{~cm}^{3}$ to compensate for errors that might have been encountered in the course of the experiment. Schematic diagram of the experiment as described elsewhere. [18].

\section{Results and Discussion}

With a solid minerals concentration of $3 \mathrm{~g}$ per $100 \mathrm{~mL}$ in acid solution, mildsteel in acidic talc solution deposited about the same quantity of material loss in control, other minerals deposited varying more quantities. The weight loss by the mildsteel in various solid minerals took the order of talc $<$ gypsum $<$ haematite $<$ alumina $<$ ironchromite $<$ feldspar.

\subsection{Adsorption Characteristics}

In Figure 2, Talc without plant extract inhibited more than when plant extract was added as the hydrogen gas released by the three different solutions were in the order talc $<$ talc with extract $<$ acid solution. Thesame order was recorded for gypsum in Figure 3.

Inhibition efficiency of both talc and gypsum falls within the $1^{\text {st }}$ hour but improved by the next hour. For the period of 8 hours the inhibition efficiency of Talc was averagely maintained at $70 \%$ and gypsum was on an average of $50 \%$ as indicated in Figure 6. Corrosion rate of steel in various media are in the order Control $>\mathrm{SA}+$ Gypsum $>\mathrm{SA}+$ Talc $>$ Gypsum $>$ Talc as shown in Figure 6. As corrosion of of $\mathrm{SA}+\mathrm{Gypsum}, \mathrm{SA}+\mathrm{Talc}$ and Gypsum increases with time that of the talc decreases with time. Inhibition efficiency of Gypsum mixed with Sida acuta extract initially was higher than that of Talc mixed with sida acuta extract but at $4^{\text {th }}$ hour there was an interchange of reaction where inhibition efficiency of Talc mixed with sida acuta extract increases from $10 \%$ to $41 \%$ in 8 hours. While there was gypsum mixed with same plant extract depreciated continuously from $59 \%$ to $16 \%$ as indicated in Figure 4 . It was observed that among the five minerals gypsum, hematite, feldspar, ironchromite and alumina that were tested for weight loss. The order of their Inhibition efficiency is talc $>$ gypsum $>$ haematite $>$ alumina $>$ chromite $>$ feldspar. Talc deposited least material and then followed by gypsum. This implies that talc inhibited the metal most and followed by gypsum. It is expected that if the solid minerals were to be in neutral medium and not in acid or highly alkaline medium, they could got adsorbed more effectively. Some of the minerals are ore of metals and compounds of non-metals expected to have affinity to bind with Iron. Therefore elements contained in these minerals are required to be attracted to steel and adhered to its surface by chemical reactions thereby preventing direct attack by the medium.

Figure 5 indicated the higher inhibition efficiency potential of talc to be higher than that of gypsum as both were compared together.

In Figure 6, Corrosion rate of acid increased above the control at the addition of mineral extract. The adsorption of these solid minerals on the metals with plant extract reduces the rate of corrosion. It implies iron has affinity for elements that made up its ore rather than organic constituents of plant extract. The addition of extracts hindered the affinity of the iron for the elemental components of the mineral thereby reduced the adsorption of the mineral components on the metal. Plants extracts have been reported to inhibit corrosion 
of metals [19, 20, 21, 22]. The sida acuta extracts on its own is an effective green inhibitor on metals. The mechanism of hindrances between both potential adsorbates is yet to be well understood, but could be trace from the assumptions that: Gypsum $\left(\mathrm{CaSO}_{4} \cdot 2 \mathrm{H}_{2} \mathrm{O}\right)$ is a very soluble compound, an introduction of its extract containing high concentration of sodium as mineral recorded in sida-acuta plant extracts [12]. Due to interaction between the two soluble compounds there could be formation of sodium sulphate a soluble compound which may stimulate corrosion rather than favour inhibition. Also the properties responsible for effective inhibition such as the number of adsorption active centres in the molecule, their charge density, the molecular size and the mode of adsorption may have been restructured.

The fact that sodium compound are not prone to corrosion inhibition of metal, hence the soluble calcium level decreases which reduces the amount of it available to be adsorped unto the surface of the metal and the ability to reduce corrosion decrease as shown in Figure 6. Plant extract containing high sodium content within temperature of range of $25^{\circ} \mathrm{C}$ to $60^{\circ} \mathrm{C}$ reduces the potency of solid mineral and hence reduces the adsorption or inhibiting properties of mineral solids by precipitating out of solution the soluble mineral that are adsorbable on metal surface. This makes the resultant solution to induce rather than inhibit corrosion. This confirms that pure metals are ready to return to their ore or oxide state in the presence of required substances and in the absence of organic extracts from plant with significant sodium content will retard adsorption of inhibitors on metals.

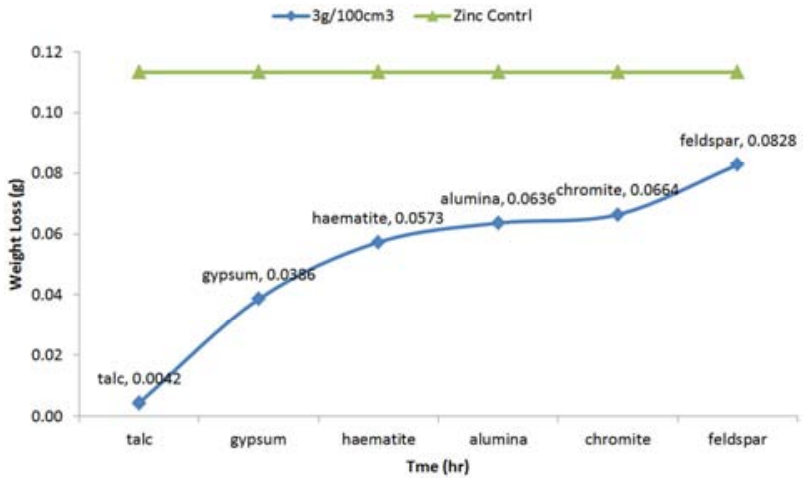

Figure 1. Graph of weight loss from mildsteel within $1 \mathrm{hr}$ in $1.0 \mathrm{M} \mathrm{HCl}$ acidic solution of Talc, Gypsum, Haematite, Chromite and Feldspar.

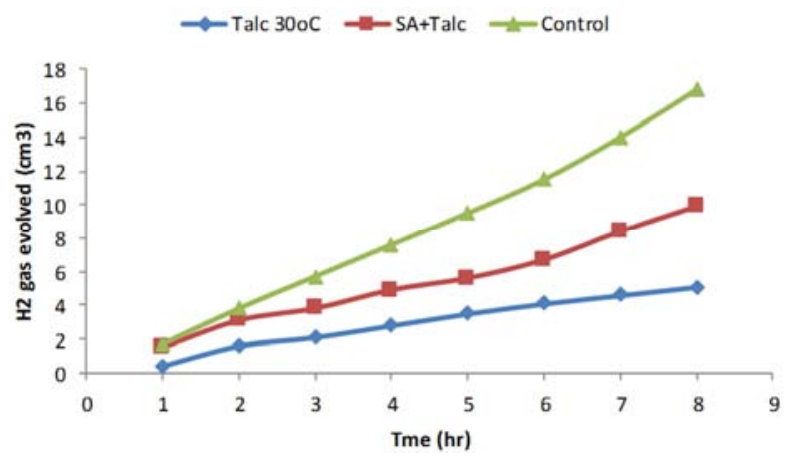

Figure 2. Graph of Hydrogen gas evolution $\mathrm{cm}^{3}$ against Time (hr) for synergized and unsynergized talc in acidic media at $30^{\circ} \mathrm{C}$.

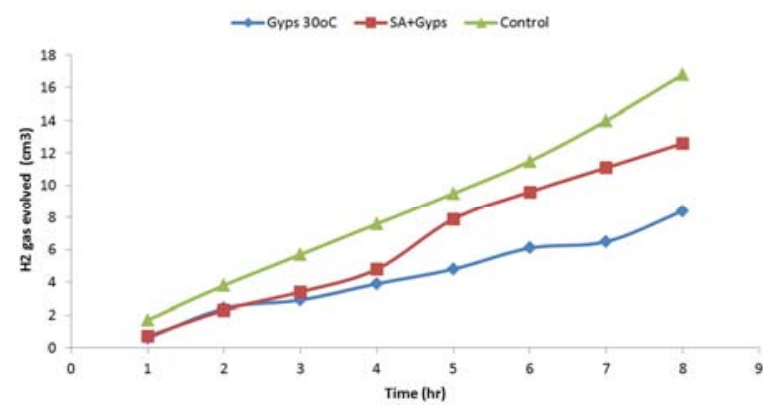

Figure 3. Graph of Hydrogen gas evolution $\mathrm{cm}^{3}$ against Time (hr) synergized gypsum and unsynergised gypsum in $1.0 \mathrm{M} \mathrm{HCl} \mathrm{acidic} \mathrm{media} \mathrm{at}$ $30^{\circ} \mathrm{C}$

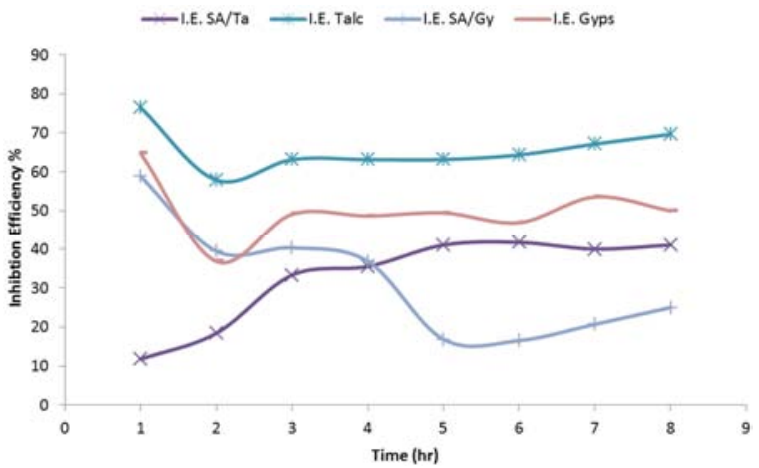

Figure 4. Graph of Inhibition efficiency \% against Time(hr) of Talc, Gypsum, SA synergized with Talc and SA synergized with Gypsum solutions on steel in acidic $1.0 \mathrm{M} \mathrm{HCl}$ media.

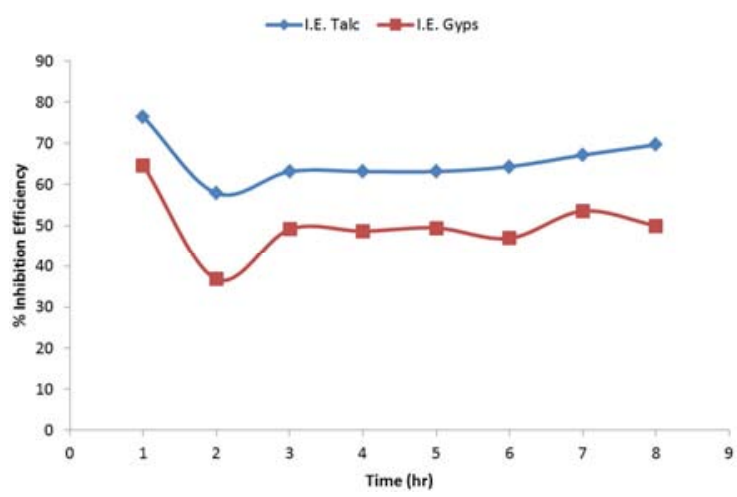

Figure 5. Graph of \% Inhibition efficiency against Time (hr) of Talc and Gypsum on steel in $1.0 \mathrm{M} \mathrm{HCl}$ acidic media.

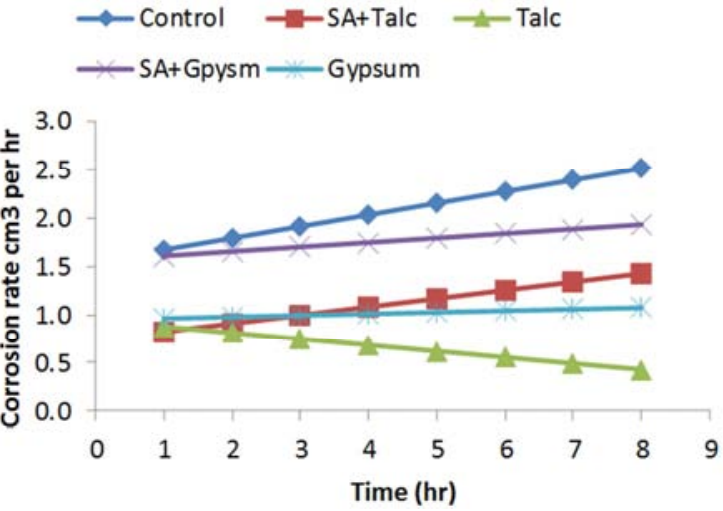

Figure 6. Graph of Corrosion rate ( $\mathrm{cm}^{3}$ per hour) of steel against Time (hr) in Talc, Gypsum, SA with Talc, SA with Gypsum 1.0M HCl acidic solution. 


\subsection{Surface Morphological Analysis}

Scanning electron microscope (SEM image in Figure 7 shows attacks of acids on several spots on the metal. The surface of steel metal was characterized by patches of corrosion products. It has made much of $\alpha$-Fe phase to dissolve in to the acid solution.

Figure 8 Energy dispersive X-ray spectroscopy (EDX) spectrum. Prominent peak of Iron with peaks of other impurities such as zirconium with oxygen and carbon. Low value of $61.49 \% \mathrm{Fe}$ and $33.38 \%$ shows high activities of corrosion on steel by the acid without extract.

SEM image in Figure 9 the high degree of protection provided by synergized extract with mild depletion of material surface covered with oxide films. This inertness down the inner part of the alloy in the acidic environment was provided for by the extract thereby reduced the depereciation rate of the material.

Figure 10 EDX spectrum showed low carbon with high oxygen peaks $84 \%$ Iron low value of $4 \%$ carbon and $11 \%$ oxygen which implies high corrosion rate.

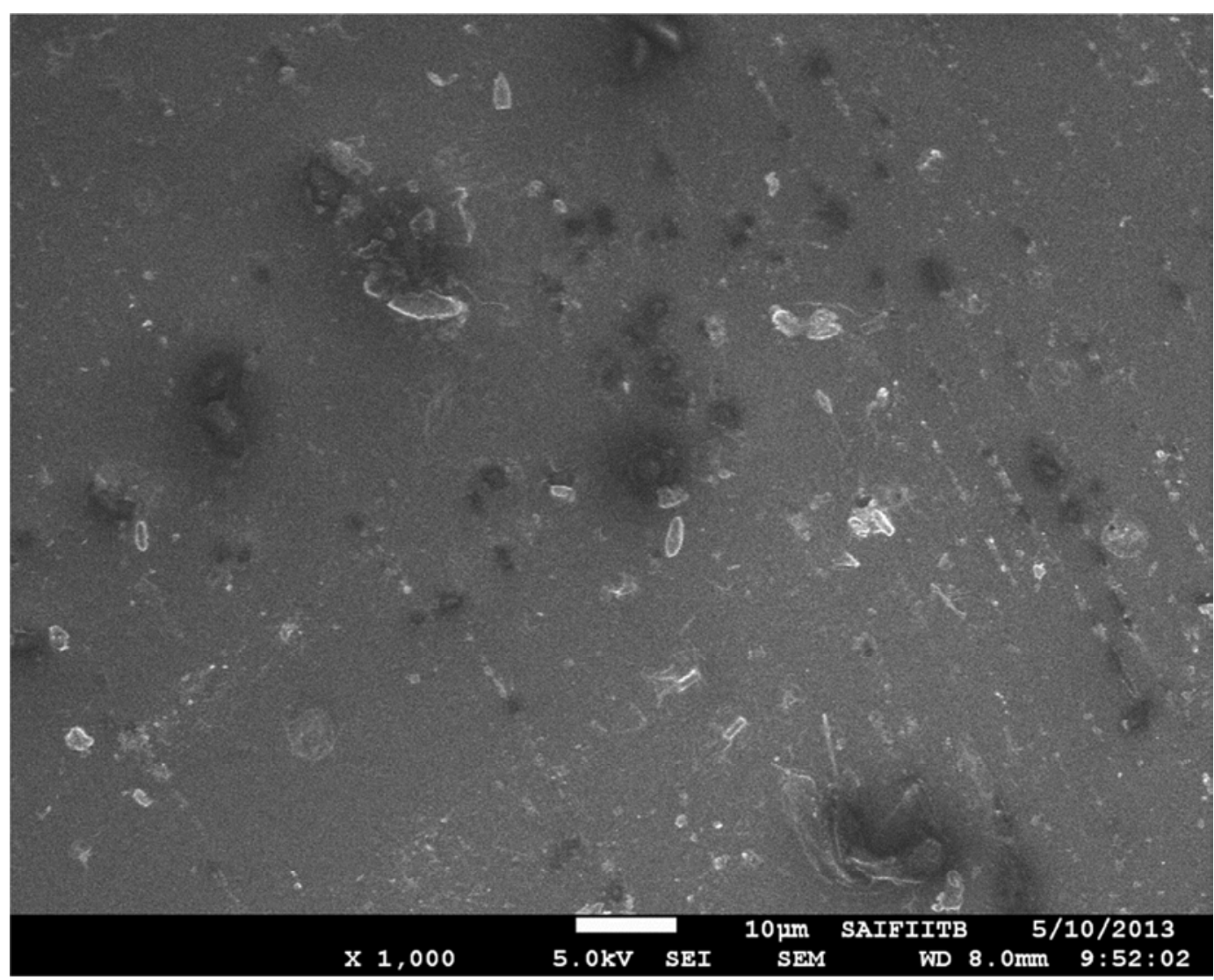

Figure 7. SEM image of steel pipe in $1.0 \mathrm{M} \mathrm{HCl}$ (control).

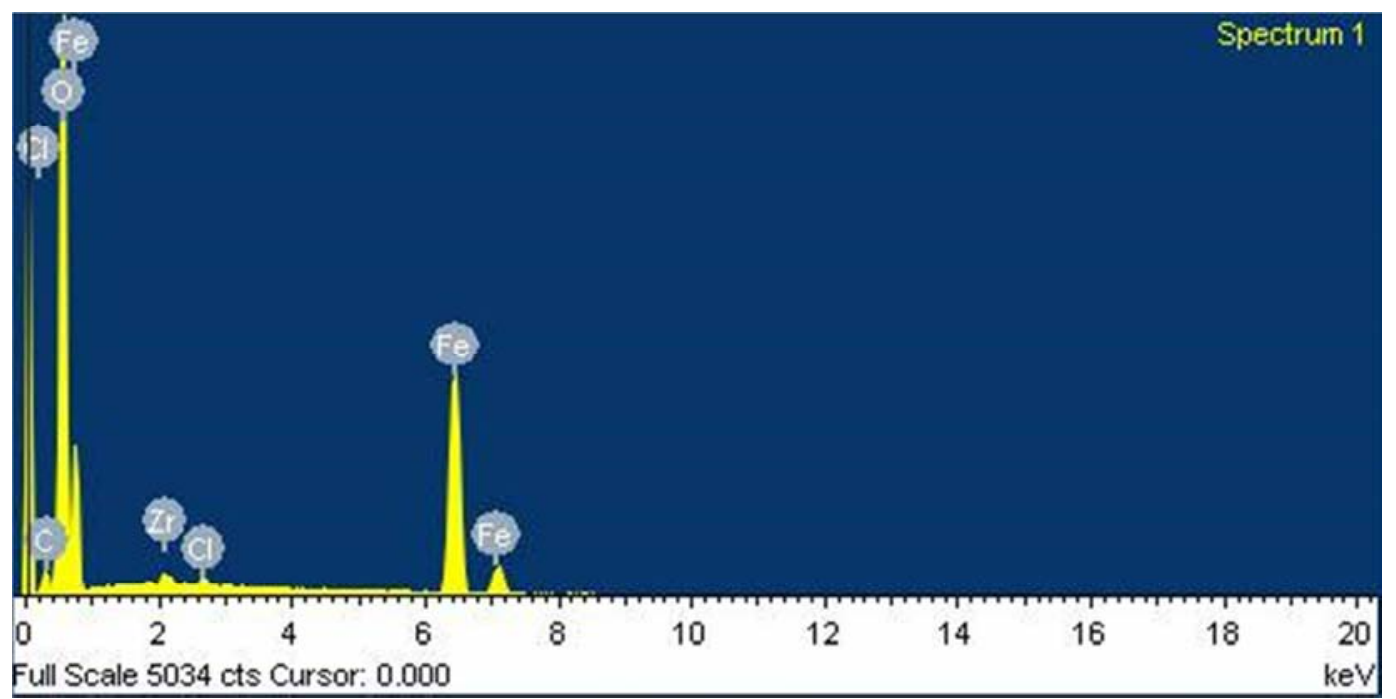

Figure 8. EDX spectrum of mild steel in 1.0M HCl (control). 


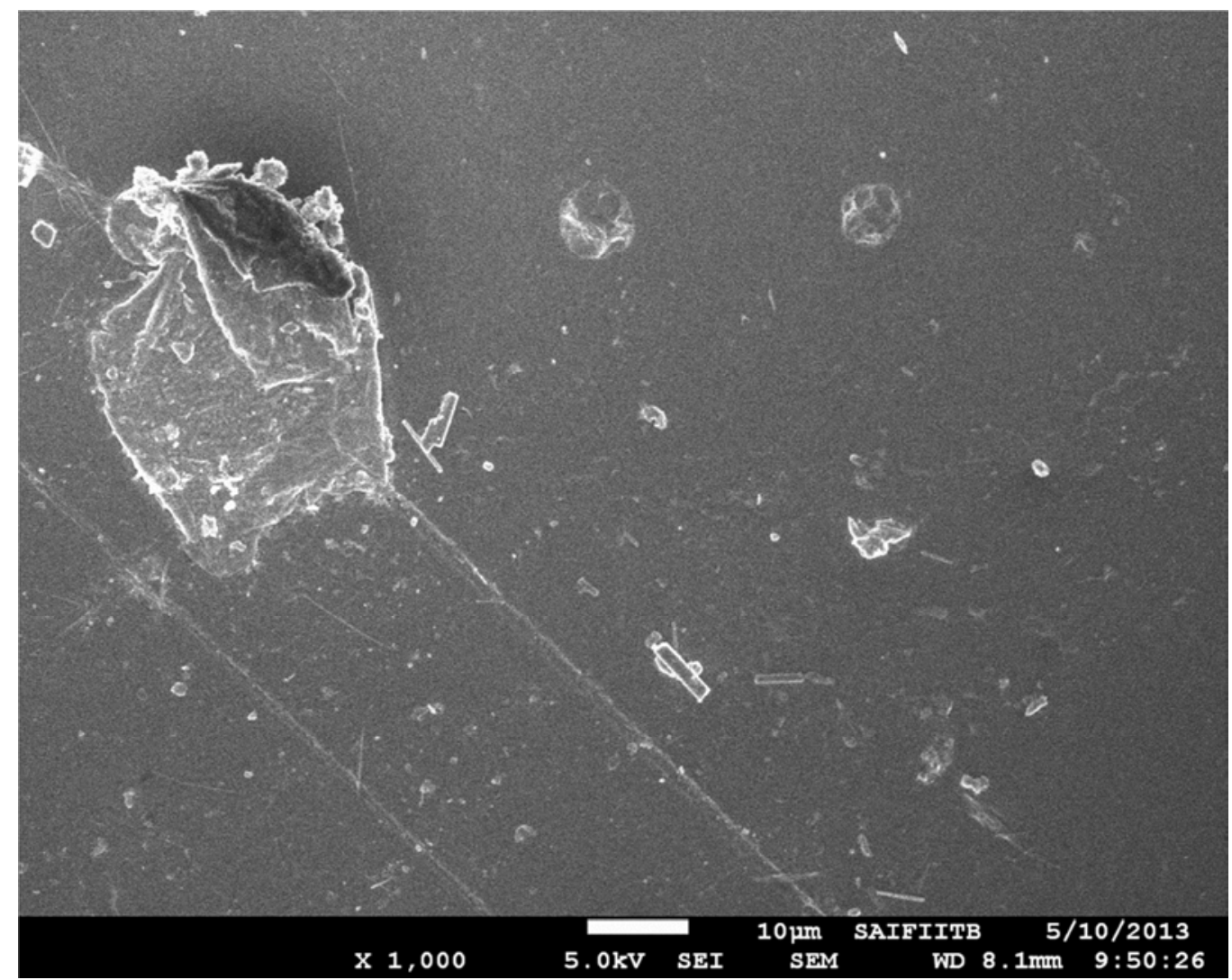

Figure 9. SEM image of mildsteel protected with gypsum and plant extract.

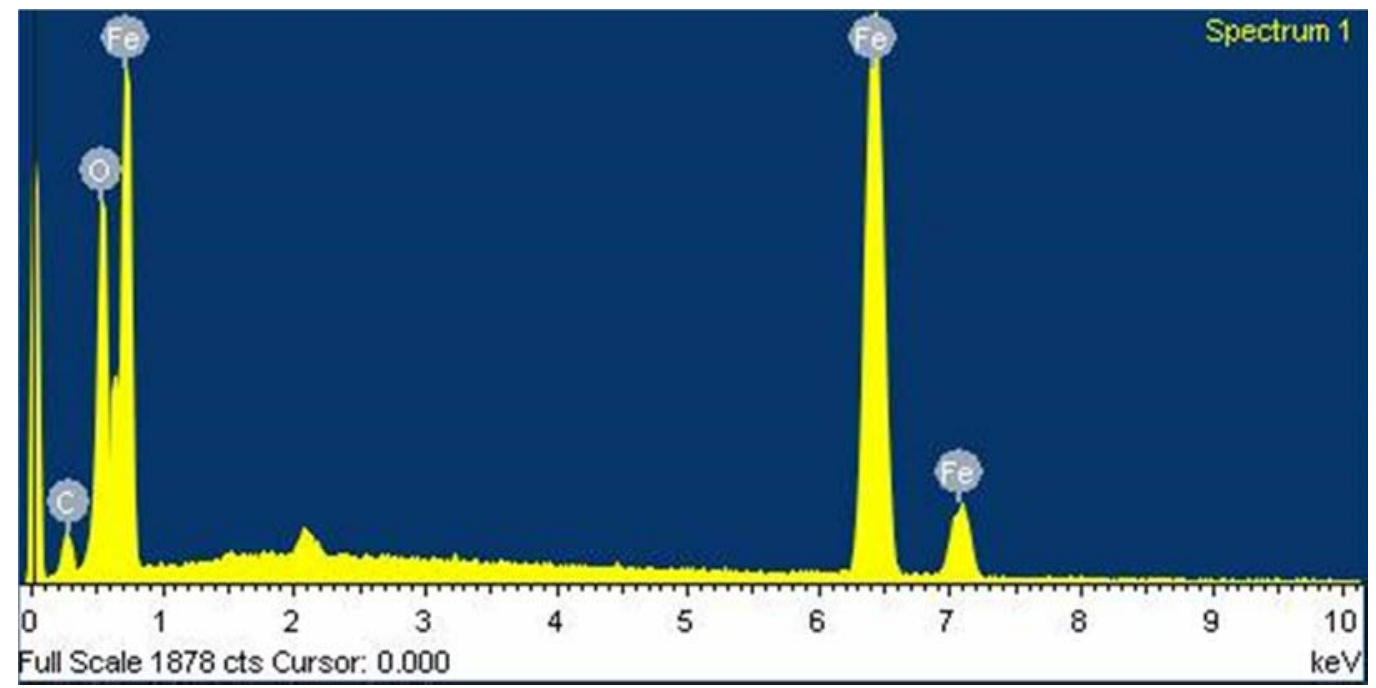

Figure 10. EDX spectrum of mildsteel protected with gypsum and plant extract.

\section{Conclusion}

The inhibitory potential of talc on the corrosion of steel was the most effective and closely followed by gypsum on steel in acidic media. The inhibition efficiency of the minerals are in the order talc $>$ gypsum $>$ haematite $>$ alumina $>$ chromite $>$ feldspar.

Plant extract and solid mineral were individually effective as inhibitors on metal but of different adsorption mechanism. The inhibiting power of solid minerals such as haematite, alumina, ironchromite and feldspar got depreciated when synergized with plant extract. This implies the corrosion inhibition effectiveness of resultant reaction product of plant extract with solid minerals expected to be complimentary in potency was confirmed lower compared with that of reactants. Elements under same chemical condition combined complimentarily to form compound. Elements in the minerals got adsorped unto the iron in steel for effective protection against corrosion or environmental aggression. Iron in the presence of other required elements under same chemical conditions combined to form ore. 


\section{References}

[1] Aliyu Abdullahi 1996 Potentials of the solid minerals industry in Nigeria: Raw Materials Research and Development Council (1996), The Amazon Book Review ISBN-10: 9782043141, ISBN-13: 978-9782043146, 208 pages. Committee on National Policy on Solid Minerals (CNPSM). Solid mineral Agency of Nigeria, 1995.

[2] Taleb H. I. and Mohamed A. Z. (2011). Corrosion Inhibition of Mild Steel using Fig Leaves Extract in Hydrochloric Acid Solution. International Journal of Electrochemical Science. 6: 6442-6455.

[3] Afolabi, A. S. 2007. Synergistic inhibition of potassium chromate and sodium nitrite on mild steel in chloride and sulphide media, Leonardo Electronic Journal of Practices and Technologies,11. p. 143-154.

[4] Muralidharan, S., Chandrasekar, R., and Iyer, S. V. K. (2000). Proc. Indian Acad. Sci. Chem Sci., 112-127.

[5] Gribble C. D. 2005 Rutley's Elements of Mineralogy, $27^{\text {th }}$ edition CBS Publishers \& Distributors 4596/1-A Indian.

[6] Nürnberger U. 1995. Corrosion of metals in contact with building materials Otto-Graf Journal, 12, 2001.

[7] Ekarat, M., Karat, T., Usuma N. and Tepiwan J. (2013). Modified Glass Batch can have increase Alumina content by using Feldspar to improve Glass Properties. Suranaree Journal of Science and Technology 20 (4): 309.

[8] Sallam, E. H., Naga, S. M. and Ibrahim D. M. (1985). Mode of Talc addition and its effect on the properties of Ceramic Bodies. Ceramic International 10 (3): 87-92.

[9] Susan Sutton and Morgan Laidlaw 1995 Ceramic industry, Material Handbook, Tom Fowler Group Publisher. No WD200956138 A, 16 (3) 215-219.

[10] Burkill, H. M., 1997. The useful plants of West Tropical Africa. 2nd Edition. Volume 4, Families M-R. Royal Botanic Gardens, Kew, Richmond, United Kingdom.

[11] Damintoti Karou, Aly Savadogo, Antonella Canini, Saydou Yameogo, Carla Montesano, Jacques Simpore, Vittorio Colizzi, Alfred S. Traore 2005, Antibacterial activity of alkaloids from Sida acuta. African Journal of Biotechnology Vol. 4 (12), pp. 1452-1457.

[12] Raimi M. M., Oyekanmi A. M and Adegoke B M. 2014.
Proximate, Phytochemical and Micronutrient Composition of Sida acuta IOSR Journal of Applied Chemistry (IOSR-JAC) e-ISSN: 2278-5736. Volume 7, Issue 2 Ver. I. www.iosrjournals.org 93.

[13] James A. O.; Akaranta O. and Awatefe K. J. (2011); Red peanut skin: an excellent green inhibitor for mild steel dissolution in hydrochloric acid solution. Alfa Universal. An International Journal of Chemistry, 2, (2), 72-78.

[14] Tsafe A. I., Hassan L. G., Sahabi D. M., Alhassan Y. and Bala B. M. 2012 Assessment of heavy metals and mineral compositions in some solid minerals deposit and water from a gold mining area of Northern Nigeria (irjgm) (2276-6618) vol. 2 (9) pp. 254-260, November.

[15] Nwajei PE, Gagophein PO (2000). Distribution of heavy metals in the sediments of Lagos Lagoon. Pak J. Sci. Ind. Res.43: 338-340.

[16] Jackson M. L. 1958 Soil Chemical Analysis, Prentice Hall Inc. 30843 Call Nopage 251.

[17] Mamatha, G. P., Pruthviraj, R. D. and Ashok, S. D. 2011. International Journal of Researching Chemistry and Environment Vol 1,: 85-88.

[18] Dawodu F. A. and Sodiya 2015 E. F. Corrosion inhibitory characteristics of Jatropha curcas on Zinc alloy in $1.5 \mathrm{M} \mathrm{HCl}$ solution. International Journal of current research Vol 7, issue 09, pp $20524-30530$.

[19] Buchweishaija 2009. Phytochemicals as green corrosion inhibitors in various corrosive media: A Review Tanz. J. Sci. Vol 35 2009, 77-92.

[20] Ambrish Singh et al 2012 Corrosion Inhibition of Carbon Steel in $\mathrm{HCl}$ Solution by Some Plant Extracts. International Journal of Corrosion Volume 2012 (2012), Article ID 897430, 20 pages http://dx.doi.org/10.1155/2012/897430

[21] Hussein H. Al-Sahlanee, Mahir H. Majeed, and Abdul-Wahab A. Sultan 2013 Corrosion inhibition of carbon steel in $1 \mathrm{M} \mathrm{HCl}$ solution by Ruta graveolens extract. Journal of Chemical and Pharmaceutical Research, 2014, 6 (5): 996-1001 www.jocpr.com.

[22] Fernando S. de Souza et al. Fernando S. de Souza, Reinaldo S. Gonçalves and Almir Spinelli* 2014 Assessment of Caffeine Adsorption onto mild Steel surface as an Eco- friendly corrosion inhibitor J. Braz. Chem. Soc. Vol. 25, No. 1, 81-90, 2014. 